\title{
Concept of Hurdle Technology for Food Safety of Food Products of Animal Origin
}

\section{Anita Chappalwar ${ }^{1}$, Vikas Pathak ${ }^{2}$, Meena Goswami ${ }^{3 *}$, Raghvendra Mishra $^{1}$ and Prashant Singh ${ }^{1}$}

${ }^{1}$ PhD Scholar Department of Livestock Products Technology, College of Veterinary

Science and Animal Husbandry, DUVASU, Mathura, Uttar Pradesh, India

${ }^{2}$ Professor and Head, Department of Livestock Products Technology, College of

Veterinary Science and Animal Husbandry, DUVASU, Mathura, Uttar Pradesh, India

${ }^{3}$ Assistant Professor, Department of Livestock Products Technology, College of

Veterinary Science and Animal Husbandry, DUVASU, Mathura, Uttar Pradesh, India

*Corresponding Author: Meena Goswami, Assistant Professor, Department of

Livestock Products Technology, College of Veterinary Science and Animal Husbandry,

DUVASU, Mathura, Uttar Pradesh, India.
Received: July 10, 2020

Published: October 30, 2020

(C) All rights are reserved by Meena

Goswami., et al.

\begin{abstract}
Foods obtained by animals like milk and meat products are highly perishable and very prone to different physic-chemical and microbial spoilage. These are nutritionally dense food with higher amount of moisture and other nutrients, hence provide conducive environment for growth of microorganisms. Hurdle technology deliberately combines existing and new preservation techniques to establish a series of preservative factors that can achieve multi-target, mild but reliable preservation effects against microbial spoilage of food. Hurdle technology usually works by combining more than one approach. The microbial stability and safety of the most traditional and novel foods is based on combinations of several preservation factors (called hurdles) and the microorganisms present in food are unable to overcome.
\end{abstract}

Keywords: Hurdle Technology; Food; Livestock Products; Multi-Targeted; Microorganisms

\section{Introduction}

Every living adventure on earth is dependent of the food for survival. A variety of food from plant animal origin consumed by human being for nutritional needs as well as satisfaction [1]. Due to unique taste of animal origin food viz, milk and milk products, poultry, egg, fish and seafoods mostly consumed by human being. Those foods included in the diet must be in the desired state i.e. neither spoiled nor contaminated. Recently spoilage and food poisoning by microorganism is a major problem. Contrarily, there is an increasing demand for natural and fresh like foods due to awareness among people. Major causes of food spoilage are growth of Bacteria, yeast and mould, reaction with light and oxygen, improper storage temperatures and time, improper ventilation, humidity, excessive delay between receiving and storing, inadequate food safety standards, predominant food spoilage is due to the growth of micro-organisms. Growth of these micro-organisms present in food unable to overcome by employing a hurdle. Hurdle is a factor, a condition or a processing step that limits, retards or prevents or reduce the microbial load. Therefore, efforts made to introduce a new preservative technique i.e. Hurdle technology to achieve multi-target safe and stable foods. Hurdle technology is a combination of selected hurdles used to extend shelf life of product by reducing hazards, so as to obtain and retain the end product safety which is stable at ambient temperature. This technology is applied for new product development and for reducing energy-consuming hurdles (such as refrigeration) or synthetic preservatives (i.e. ni- 
trites) [2]. "Hurdle Technology" is known as "Combined preservation or Barrier technology" which causes mmaximum mortality of microorganisms by a combination of hurdles [3]. Hurdle technology was developed as a new concept for the production of safe, stable, nutritious, tasty and economical foods.

\section{Need for hurdle technology}

Growing consumer health awareness Fast growing economy, employment of women, increase in the income of middle class people puts demand for shelf stable food products. In hurdle technology, hurdles are deliberately combined to improve the microbial stability and the sensory quality of foods as well as their nutritional quality of foods and economic properties. Hurdle preserved foods that are microbiologically stable become even safer during storage, especially at ambient temperature [4]. Thus, hurdle technology aims to improve the total quality of foods by application of an intelligent mix of hurdles [5].

\section{History of hurdle technology}

Hurdle term coined by Leistner and Rodel in 1976 and hurdle technology has been derived by Leistner in 1985. Renowned term Barrier technology was exploited for hurdle technology by Leistner in 1994. Thereafter Concept of Multi target preservation of food was found by Leistner in 1995. Again new term "Invisible technology" was introduced by Leistner in 1999 as a synonym of hurdle technology. Hurdle technology should be managed in accordance with the HACCP principles. Hurdle technology systems should be systematically designed, choose an ideal set of combine hurdles [6]. Preventive measures should be implemented at primary production level. Preventive measures should be implemented at plant level to minimize post contamination of the intermediate and end products.

\section{Objectives of hurdle technology}

- To employs the intelligent combination of different hurdles or preservative techniques to achieve multi- target preservation effects.

- $\quad$ To enhance product safety and stability.

- To increase the shelf life of product at ambient temperature.

Mechanism of hurdle technology: Combination of factors employed in hurdle technology mainly alters the homeostatic mechanism for micro-organisms.

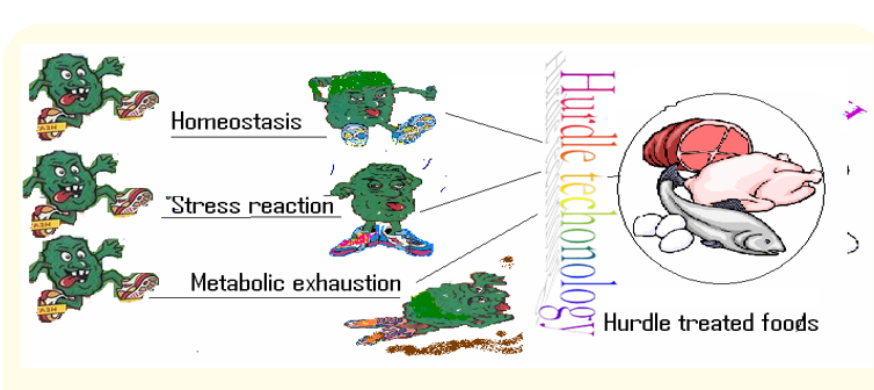

Figure

1. Homeostasis: In animal origin food preservation homeostasis of micro-organism is a key phenomenon. Homeostasis is the constant tendency of microorganisms to maintain a stable and balanced (uniform) internal environment. Preservative factors functioning as hurdles can disturb homeostasis several homeostasis mechanisms simultaneously [7]. Some of the examples of homeostasis in the body are regulation of temperature and balance between acidity and alkalinity $(\mathrm{pH})$. These factors are disturbs internal status (E.g. Cell membrane, DNA, $\mathrm{pH}, \mathrm{a}_{\mathrm{w}}$ and enzyme system) of higher organisms as well as microorganisms [6], thereby check growth of microorganism and causing them to remain inactive or even die. Therefore, meat preservation is achieved by disturbing the homeostasis of microorganisms permanently [8].

2. Stress reaction: Due to disturbance in internal status of microorganism stress reaction result. Some microbes attain resistance or may become more potent under stress conditions as they synthesize stress shock proteins. The synthesis of stress shock protein is affected by several factors like $\mathrm{pH}$, water activity, ethanol, heat, etc. The different responses of microbes under stress conditions might hamper the food preservation. Exposure to multiple stresses simultaneously activates the energy utilizing synthesis of several stress shock proteins, in turn making the microbes metabolically weak. Therefore, multitarget preservation of foods could be an efficient approach towards reducing the synthesis of stress shock proteins and in food preservation [9]

3. Metabolic exhaustion: It is another phenomenon of practical importance is metabolic exhaustion of microorganism It is also called "Auto-sterilization" of food In this phenomenon the micro-organism in the stable hurdle technology food strain effort possible repair mechanisms for their homeostasis to over- 
come the hostile environment by doing this they completely used up their energy and die if they become exhausted Give microbiologically stable, fresh, more safe food during storage at ambient temperature.

Principal hurdles used for food preservation [10]

\begin{tabular}{|l|c|c|}
\hline \multicolumn{1}{|c|}{ Parameter } & Symbol & Application \\
\hline High temperature & $\mathrm{F}$ & Heating \\
\hline Low temperature & $\mathrm{T}$ & Chilling, freezing \\
\hline Reduced water activity & $\mathrm{a}_{\mathrm{w}}$ & Drying, curing, conserving \\
\hline Increased acidity & $\mathrm{pH}$ & Acid addition or formation \\
\hline Reduced redox potential & $\mathrm{E}_{\mathrm{h}}$ & $\begin{array}{c}\text { Removal of oxygen or ad- } \\
\text { dition of ascorbate }\end{array}$ \\
\hline Biopreservatives & & $\begin{array}{c}\text { Competitive flora such } \\
\text { as microbial fermentation }\end{array}$ \\
\hline Other preservatives & & Sorbates, sulfites, nitrites \\
\hline
\end{tabular}

Table 1

\section{Classification of potential hurdles [11, 12]}

There are 60 different Potential hurdles have been identified for use in the preservation of food.

\begin{tabular}{|l|c|}
\hline \multicolumn{1}{|c|}{$\begin{array}{c}\text { Types of } \\
\text { hurdles }\end{array}$} & Example \\
\hline Physical & $\begin{array}{c}\text { Aseptic packaging, electromagnetic energy } \\
\text { (microwave, radio frequency, pulsed magnetic } \\
\text { fields, high electric fields), high temperatures } \\
\text { (blanching, pasteurization, sterilization, } \\
\text { evaporation, extrusion, baking, frying), ioniz- } \\
\text { ing radiation, low temperature (chilling, freez- } \\
\text { ing), modified atmospheres, packaging films } \\
\text { (including active packaging, edible coatings), } \\
\text { photodynamic inactivation, ultra-high pres- } \\
\text { sures, ultrasonication, ultraviolet radiation }\end{array}$ \\
\hline $\begin{array}{l}\text { Physico-chem- } \\
\text { ical }\end{array}$ & $\begin{array}{c}\text { Carbon dioxide, ethanol, lactic acid, lacto- } \\
\text { peroxidase, low pH, low redox potential, } \\
\text { low water activity, Maillard reaction products, } \\
\text { organic acids, oxygen, ozone, phenols, phos- } \\
\text { phates, salt, smoking, sodium nitrite/nitrate, } \\
\text { sodium or potassium sulphite, spices and } \\
\text { herbs, surface treatment agents }\end{array}$ \\
\hline Microbial & $\begin{array}{c}\text { Antibiotics, bacteriocins, competitive flora, } \\
\text { protective cultures }\end{array}$ \\
\hline Miscellaneous & $\begin{array}{c}\text { Monolaurin, free fatty acids, chitosan and } \\
\text { chlorine. }\end{array}$ \\
\hline
\end{tabular}

Table 2
High-temperature

I. Pasteurization: A Pasteurization procedure varies with combinations time and temperature (HTST, LTLT and UHT). It is the process in which food product heated at $63^{\circ} \mathrm{C}$ for $30 \mathrm{~min}$ utes or $72^{\circ} \mathrm{C}$ for 15 seconds then immediately cooled to $10^{\circ} \mathrm{C}$ or below. Shorter heating times of pasteurization improved flavor of the product. Pasteurization method kills pathogens and substantially reduces number of spoilage microorganisms.

II. Sterilization: In this method product get exposed to severe heat treatment $\left(121.1^{\circ} \mathrm{C}\right)$, due to which spores also get destroyed. This technique helpful for development of "shelf-stable" product.

Low temperature

i. Refrigeration: This is a Short-term preservation (days to weeks) done at temp $0^{\circ} \mathrm{C}$ to $4^{\circ} \mathrm{C}$ for most foods. This method slows down microbial growth and some pathogens e.g. C. botulinum (type E), Listeria, Aeromonas and Achromobacter still grow at this refrigeration temperature.

ii. Freezing: It is Long-term preservation (months to years), generally done at $-18^{\circ} \mathrm{C}$ to $-30^{\circ} \mathrm{C}$. Freezing stops microbial growth.

Reduced water activity $\left(a_{w}\right)$ : Water isrequired for microbial growth, enzyme/chemical reactions, where water activity represents the amount of water required for growth of microorganisms. Reduction of water activity results in less availability of water to microbes. Most bacteria cannot grow below $\mathrm{a}_{\mathrm{w}}=0.85$. Most yeasts and molds cannot grow below $\mathrm{a}_{\mathrm{w}}=0.65$. Water activity of the products can be reduced bydehydration or by addition of solutes, which helps in the extension of storage life.

Increased acidity (lowered pH): Acidity slows down growth of spoilage organisms and pathogens. Pathogens and spores cannot germinate at $\mathrm{pH}<4.5$. In milk and meat product acidification can be achieved by employing competitive microorganisms (e.g. lactic acid bacteria) in fermentation process as well as by addition of acids during processing of products [13]. Main organic acids used for preservation of food are lactic acid (0.5 - 2\%), citric acid (0.2 $2 \%$ ) and acetic acid (1 - 2\%). pH of different food products are as following. 


\begin{tabular}{|c|c|}
\hline Product & pH \\
\hline Milk & $6.4-6.8$ \\
\hline Ground beef & $5.1-7.2$ \\
\hline Ham & $5.9-6.1$ \\
\hline Fish & $7.0-7.3$ \\
\hline Oysters & $4.8-6.3$ \\
\hline Egg albumin & 7.6 \\
\hline Shelf stable pork sausages & 5.9 \\
\hline
\end{tabular}

Table 3

Reduced oxygen supply: Oxygen supply to microbes can controlled by maintain anaerobic conditions. Low oxygen inhibits the aerobic pathway, which results in death of organisms.

Preservative: The most commonly used food preservatives in food products are nitrites, sorbate, sulfite. These preservatives are added in low levels $(\mathrm{mg} / \mathrm{kg}$ ) for specific applications and found effective in iinhibiting growth of bacteria, yeasts, moulds.

\section{Hurdle technology in foods of animal origin}

In dairy industry, loss of valuable nutrients and its sensory characteristics during thermal processing occurs due to substantial heat exposure. To preserve the nutrients and quality of milk products implementation of hurdle technology is a good alternative. Rao and Patil (1992) extended shelf life of paneer by hurdles technology mild heat treatment, minor reduction in water activity (0.95) and acidification ( $\mathrm{pH} 5.0$ ) to 14 days at $30^{\circ} \mathrm{C}$ with addition of $1 \%$ each of sodium chloride, sucrose and glycerol [14]. Thereafter they formulated paneer curry to have a water activity of 0.95 , $\mathrm{pH}$ of 5.0 and potassium sorbate content of $0.1 \%$ to extended its shelf life. The product kept well for about 1 month and had a better quality than the heat-sterilized product stored under similar conditions $\left(30^{\circ} \mathrm{C}\right)[15]$. Sachdeva and Singh (1990) extended the shelf life of paneer cubes of small size $(1.0 \times 0.25 \times 0.5$ inches $)$ by 8 $-10^{\circ} \mathrm{C}$ dipping of paneer in $5 \%$ brine, acidified brine $(5 \% \mathrm{NaCl}, \mathrm{pH}$ $5.5)$ and hydrogen peroxide solution $(0.2 \%, v / v)$ with or without delvocid $(0.5 \%, \mathrm{w} / \mathrm{v})$ to $22,20,32$ and 22 days respectively compared to 10 days for control [16]. Gasasase (poppy seeds) payasum is product prepared from poppy seeds and rice and by application of retort processing ( $\mathrm{f}_{0}$ value 6 at steam pressure of 1.04 bar). Marginal change in its $\mathrm{pH}$, acidity and $\mathrm{HMF}$ content and viscosity take place during storage which led to extension of its shelf-life to 6 weeks at $37^{\circ} \mathrm{C}$ temperature [17]. Hossain (1994) employed hur- dles like heating, acid coagulation, addition of sugar and sorbate, smoking, drying and packaging in a closed container to shelf stable product Dudhchurpi, which is mainly prepared in Himalaya region (Bhutan, Sikkim and Dargeeling) from milk of yak or cow [18]. The $\mathrm{pH}$ of culture and natural preservative like ginger major hurdles during preparation of a famous south Indian dish curd [19]. The principles of the most common Hurdles Bactofugation, Competitive microflora, Microfiltration: Ripening (ageing), Thermization, Ultrasonication, Electromagnetic energy treatment and Low-intensity irradiation used in dairy industry to control microbial load.

Hurdles relatively low temperature, appropriate relative humidity, absence of light and slight anoxia crates positive effect on meat products and extends the shelf life. Rathod (2005) developed shelf stable curry using potential hurdle used are salt, $\mathrm{pH}$, preservatives, packaging material and heating. Shelf life of product was increased up to 10 days at ambient temperature [20]. Karthikeyan., et al. (2000) used water activity (aw) and pH as variable hurdles as well as vacuum packaging, preservatives and heat treatment as constant hurdles for shelf life extension of caprine keema [21]. Lara., et al. (2013) prepared Charqui meats to observe the possibility of development of enterotoxigenic Staphylococcus aureus and Clostridium botulinum proteolytic type B spores and their toxins [22]. Chawla and Chandler (2004) used combination of hurdles irradiation, reduced water activity, and vacuum packing) to in preventing the growth of Clostridium sporogenes in shelf stable meat products [2004]. The studies demonstrated that a combination of the above hurdles results in microbiologically safe and shelf-stable meat products. Thomas., et al. (2008) developed pork sausages incorporating different hurdles viz, low $\mathrm{pH}$, low water activity, vacuum packaging and post package reheating and observed that shelf life of pork sausage was increased upto 6 day at ambient temperature [24].

\section{Novel techniques used in hurdle concept}

Recently, consumers are demanding are for minimally processed food products without additives, improved safety and shelf life. Hurdle technology is a one of the promising technology which reduces losses of nutritional and sensory quality and improves food safety [25]. Homeostasis, metabolic exhaustion, and stress reactions of micro-organisms are the basic aspect of hurdle technology and cemented the way for the application of multi target preservation of foods. The principles of Bactofugation, Competi- 
tive microflora, Microfiltration: Ripening (ageing), Thermization, Ultrasonication, Electromagnetic energy treatment and Low-intensity irradiation used to reduce microbial loads in milk and milk products are: At present, physical, non-thermal processes (high hydrostatic pressure, oscillating magnetic fields, pulsed electric fields, light pulses, etc.) receive considerable attention (Nonthermal Processing), since in combination with other conventional hurdles they are of potential use for the microbial stabilization of fresh-like food products, with little degeneration of nutritional and sensory properties.

A Novel Biopreservative Micocin ${ }^{\circledR}$ offers a valuable hurdle. Basis for Preservation of Micocin ${ }^{\circledR}$ Technology with Lactic Acid Bacteria, a naturally occurring group of bacteria found in a many foods, especially on vacuum-packed RTE meats. It is a natural biopreservative, specifically targets Listeria. Listeria is a major organism concern for Food Safety. Micocin is an effective hurdle for inhibition of Listeria growth on RTE meats. Addition of micocin used in manufacture of Cheese, Yoghurt, Meats (preservation and fermentation enhances their insurance against outbreaks of Listeriosis. Micocin of three types Micocin ${ }^{\circledR}$ I, Micocin ${ }^{\circledR}$ II, Micocin ${ }^{\circledR}$ X. these are natural ingredients easily available in market as a preservative.

\begin{tabular}{|c|c|c|}
\hline $\begin{array}{c}\text { Type of } \\
\text { micoccin }\end{array}$ & Main benefit & $\begin{array}{c}\text { Additional } \\
\text { benefits }\end{array}$ \\
\hline Micocin ${ }^{\circledR}$ I & $\begin{array}{c}\text { Prevents growth of Listeria spp. } \\
\text { throughout shelf-life. }\end{array}$ & $\begin{array}{c}\text { Controlled } \\
\text { spoilage }\end{array}$ \\
\hline Micocin $^{\circledR}$ II & $\begin{array}{c}\text { Immediate reduction of Listeria } \\
\text { spp. and prevention of growth } \\
\text { throughout shelf-life. }\end{array}$ & $\begin{array}{c}\text { Controlled } \\
\text { spoilage with } \\
\text { protective } \\
\text { microflora. }\end{array}$ \\
\hline Micocin $^{\circledR} \mathrm{X}$ & $\begin{array}{c}\text { Designed to add directly during } \\
\text { pre-processing of meat emulsion. } \\
\text { Improves the preservative effec- } \\
\text { tiveness of lactate and diacetates. }\end{array}$ & \\
\hline
\end{tabular}

Table 4

There has been increasing in interest of design and application of hurdle technology in food preservation. For that purpose National and International funds have now been established. In India there is big problem of electric -interruption so there will be increasing demand for Hurdle Treated Foods (HTFs) in future due to awareness among people. It is an advanced technology for preservation of food which is highly perishable in nature.

\section{Conclusion}

Hurdle technology is novel and ambitious goal for optimal food preservation including food of animal origin. It includes multi-target preservation of food utilizing various factors as hurdles. This method work, on the physiological responses of micro-organism during meat preservation (homeostasis, stress reaction and metabolic exhaustion) and result in increase in self life of meat product at ambient temperature. Hurdle technology if used in appropriate way is good tool for achieving safe and tasty food products of high quality. This approach is not only valid for modern processes preservation procedure but also being used for traditional food products since immortal times. This will make it's way to longer the shelf life of food of animal origin to fighter against malnutrition and hunger even in deficiency of facilities like refrigeration and freezing.

\section{Bibliography}

1. Pal M. "Preservation of various foods". Ph.D. Lecture, Addis Ababa University, College of Veterinary Medicine and Agriculture, Debre Zeit, Ethiopia (2014): 1-11.

2. Ananou S., et al. "Biopreservation, an ecological approach to the safety and shelf-life of foods". Communicating Current Research and Educational Topics and Trends in Applied Microbiology A. Mendez-Vilas (Edition) (2007): 475.

3. Singh S and Shalini R. "Effects of hurdle technology in food preservation: A review". Critical Review on Food Science and Nutrition 56 (2016): 641-649.

4. Leistner L and Gorris LGM . "Foodpreservation by hurdle technology". Trend in Food Science and Technology 6 (1995): 35-37.

5. Leistner L. "Further Developments in the Utilization of Hurdle Technology for Food Preservation". Journal of Food Engineering 22 (1994): 421-432.

6. Leistner L. "Use of combined preservative factors in foods of developing countries". The Microbiological Safety and Quality of Food, Vol. I (editions. B.M. Lund, A.C. Baird-Parker, and G.W. Gould), Gaithersburg: Aspen Publishers, Inc (2000): 294-314.

7. Raso J., et al. "Sporulation temperature affects initiation of germination and inactivation by high hydrostatic pressure of Bacillus cereus". Journal of Applied Microbiology 85 (1998): $17-24$. 
8. Gould GW. "Homeostatic mechanisms during food preservation by combined methods". In: Barbosa-Canovas, G.V., WeltiChanes, J. (Editions.), Food Preservation by Moisture Control: Fundamentals and Applications, Technomics Publishing Lancaster, Pennsylvania (1995): 397-410.

9. Leistner $L$ and Rodel W. "The significance of water activity for microorganisms in meats". In Water Relations of Foods, ed. R.B. Duckworth. Academic Press, London (1975): 309-323.

10. Pal M., et al. "Hurdle Technology: A novel approach for Food Preservation". Beverage and Food World 44.1 (2017): 20-26.

11. Sabnis S., et al. "Use of chitosan in compressed tablets of diclofenac sodium: inhibition of drug release in an acidic environment". Pharmaceutical Development and Technology 2.3 (1997): 243-255.

12. Ohlsson $\mathrm{T}$ and Bengtsson $\mathrm{N}$ "Minimal processing technologies in the food industries". Woodhead Publishing, Sawston (2002): 66-84.

13. Gálvez A., et al. "Biopreservation of Meats and Meat Products". In: Food Biopreservation. SpringerBriefs in Food, Health, and Nutrition. Springer, New York, NY (2014): 135-152.

14. Rao KJ and Patil GR "Water activity lowering ability of some humectants in paneer". Indian Journal of Dairy and Bioscience 10 (1992): 121-122.

15. Rao KJ and Patil GR. "Development of ready to eat paneer curry by hurdle technology". Journal of Food Science and Technology 36 (1999): 37-41.

16. Sachdeva S and Singh S. "Shelf-life of paneer affected by antimicrobial agents, Part I, Effect on sensory characteristics". Indian Journal of Dairy Science 43 (1990): 60-63.

17. Geetha P. "Studies on physicochemical and sensory characteristics of retort processed gasagase payasam". M. Tech. Thesis submitted to National Dairy Research Institute (southern campus), Bangalore (2005).

18. Hossain SKA. "Technological Innovation in Manufacturing dudhchurpi". Ph.D. Thesis, University of North Bengal, Siliguri, India (1994): 122.
19. Balasubramanyam BV., et al. "Application of hurdle technology for large scale production of curd rice". Annual Report 2003 and 04, National Dairy Research Institute (Southern Campus), Bangalore (2004).

20. Rathod KS. "Application of hurdle technology for preservation of ready to eat chicken curry". M. V. Sc. Thesis submitted to MAFSU, Nagpur (2005).

21. Karthikeyan J., et al. "Application of hurdle technology for the development of caprine keema and its stability at ambient temperature”. Meat Science 54 (2000): 9-15.

22. Lara JA., et al. "Evaluation of survival of Staphylococcus aureus and Clostridium botulinum in charqui meats". Meat Science 65.1 (2003): 609-613.

23. Chawla SP and Chandler R. "Microbiological safety of shelf-stable meat products prepared by employing hurdle technology". Food Control 15 (2004): 559-563.

24. Thomas RA., et al. "Development of shelf stable pork sausages using hurdle technology and their quality at ambient temperature $\left(37 \pm 1^{\circ} \mathrm{C}\right)$ storage". Meat Science 79.1 (2003): 1-12.

25. Khan I., et al. "Hurdle technology: A novel approach for enhanced food quality and safety e A review". Food Control (2016): 1-16.

\section{Assets from publication with us}

- Prompt Acknowledgement after receiving the article

- Thorough Double blinded peer review

- Rapid Publication

- Issue of Publication Certificate

- High visibility of your Published work

Website: www.actascientific.com/

Submit Article: www.actascientific.com/submission.php

Email us: editor@actascientific.com

Contact us: +919182824667 